\title{
COPPER, SILVER, LEAD, VANADIUM, AND URANIUM ORES IN SANDSTONE AND SHALE.
}

\author{
WALDEMAR LINDGREN.
}

General Characteristics.-In widely separated parts of the world and generally far away from igneous rocks ores of copper, lead, vanadium and uranium appear in extensive series of sandstone and shale under circumstances which indicate a common mode of origin. They are usually of low tenor and in the majority of cases can not be utilized. The primary ores are chalcocite, with small amounts of bornite, chalcopyrite and pyrite; galena; roscoelite, a vanadium mica; carnotite, a vanadate of uranium. Small amounts of nickel, cobalt, molybdenum, barium, and selenium are often found. While all these sometimes occur together, they are more commonly segregated into separate deposits in which one metal predominates. Gangue minerals are conspicuously absent or confined to a little calcite, barite, and gypsum, the latter probably secondary. Where exposed to the atmosphere oxidized minerals develop.

The deposits are rather conspicuously confined to certain formations or members within the Permian, Jurassic, or Triassic, but do not ordinarily follow a given horizon without frequent interruptions. Characteristic occurrences appear in fractured and brecciated beds or where plant fossils abound. More rarely the ores appear in fissures in the same formations where they were evidently deposited by ascending or descending atmospheric waters. Occasionally the ores have been leached and carried down into the lower strata. They appear to have no connection with thermal springs.

Origin.-In their present form the ores are assuredly epigenetic, but the evidence equally clearly points to their having been concentrated by atmospheric waters from small quantities 
of metals disseminated in the rocks. It is believed, though the evidence of this is less direct, that the metals were carried down as sediments and solutions from older ore deposits in the adjacent continental areas. The sediments are in many cases of shallow water marine origin, but in part certainly land deposits, and often indicate arid conditions.

The waters which concentrated the ores are believed to have been mainly sodium chloride and calcium sulphate solutions containing sulphates and perhaps chlorides of copper and lead. Mineral association and geological features indicate low temperature deposition at shallow depths, probably well below $100^{\circ} \mathrm{C}$., but below the zone of direct oxidation. Very likely these ores have been forming continuously since the establishment of active water circulation in the beds; in favorable places below the surface concentration may now be in progress.

COPPER AND LEAD DEPOSITS IN SANDSTONE.

European Occurrences. ${ }^{1}$-The European occurrences are confined to the Permian and the Triassic, both largely ages of arid climate and saline deposits.

The Russian Permian, extending far west from the Urals, consists in its lower division of sandstones, marls, in part marine, and conglomerates. The sandstones are rich in vegetable remains. Copper ores are found over wide areas, but have not been worked extensively of late years. They are said to average 0.9 per cent. copper. The chalcocite ores replace plant remains and tree trunks, or appear in the cement of the sandstones. The minerals mentioned are (besides secondary malachite and azurite) : chalcocite, chalcopyrite, tetrahedrite (?), barite, vanadinite, volborthite (vanadate of copper and calcium).

Much interest has lately been taken in the copper deposits of the Khirgiz Steppes ${ }^{2}$ between the Urals and the Altai in the

${ }^{1}$ For an excellent review of European localities, as well as complete index of literature, in part difficultly accessible, see Stelzner-Bergeat: Die Erzlagerstätten, I904, pp. 388-439.

${ }^{2}$ Addiasseurch, A., "A Journey to Central Asia," Trans. Inst. Min. and Met., I7, 1907-1908, pp. 498-522. 
Karkaralinsk and Akmolinsk districts. Very rich copper ores have here been found in sandstones said to be Paleozoic, and they consist of malachite, azurite, bornite; little exact information is available. At Nankat, west of Kokand in Turkestan, new discoveries have been made of metallic copper in sandstones and gypsiferous marls of Tertiary age; fossil wood and chalcocite are also found. ${ }^{1}$

In Bohemia ${ }^{2}$ the lower Permian (Rothliegende) along the south slope of the Riesengebirge contains similar ores. The lower beds carry chalcocite with a little silver, also some pyrite in several horizons of the arcosic rocks, which contain abundant plant remains.

The Permian of the Palatinate in Germany yields nodules of chalcocite and chalcopyrite.

Most important from an economic standpoint and curiously connected with the mineralization of the Permian is the "Kuperschiefer," or copper-bearing shale of Central Germany; this is described on a subsequent page $(578)$.

Over a large part of Western Europe the Trias is a copperbearing formation, and together with the copper more or less lead is found.

In England, at Alderley Edge and Mottram St. Andrews, ${ }^{3}$ south of Manchester, copper ores have been mined. They occur in the cement of Triassic sandstones and conglomerates and consist of copper carbonates, galena, pyromorphite, and vanadinite; also some barite, manganese and cobalt. The ores are said to carry at most I.4 per cent. copper. The mineral mottramite, a vanadate of copper and lead, was discovered at this place.

In Germany the Trias is divided in three parts: The lower variegated sandstone ("Buntsandstein") ; the middle shell limestone (Muschelkalk); and the upper marls and sandstones (Keuper); of these the lower and upper divisions contain lead and copper ores.

${ }^{1}$ Beck, R., "Lehre von den Erzlagerstätten," I909, 2, I72.

${ }^{2}$ Gürich, F., Z. f. prakt. Geol., I893, pp. 370-37I.

${ }^{3}$ Phillips, and Louis, “Ore Deposits," I896, pp. 266-269. 
In Bavaria the Keuper contains galena and chalcopyrite in certain gypsiferous beds, and this is associated with a little zincblende and barite.

In Württemberg galena with a little oxidized copper ore and barite is generally distributed in the Corbula bed of the lower, gypsiferous Keuper. In the Palatinate, the littoral characteristics are plainly indicated and there is an abundance of fossil wood; in two horizons the sandstones contain galena and cerussite and were formerly worked.

In the "Buntsandstein" in Prussia and Lorraine, near Saarlouis and other places, a horizon known as the Voltzia sandstone, is particularly rich in lead and copper ores, which at times have been worked. The bed contains abundant plant remains. The minerals are cerussite, galena, chalcocite (?) and carbonates.

The best known deposits of the Trias are those of Commern and Mechernich, not far from Aix-la-Chapelle, in Prussia. Lead ores have been mined here for several hundred years, but it is reported that the mines may soon be closed. The ores are of low grade and are mined in open cuts by removing about I 30 feet of overburden. In 1903 the ores averaged I.5 per cent. lead (Stelzner-Bergeat). The ores are galena, cerussite, oxidized copper ores, with a little chalcopyrite and barite, the latter filling veins and veinlets in the sandstone. A little silver, nickel and cobalt are present. The thickness of the ore-bearing sandstone is about 20 meters. Very remarkable is the general occurrence of the galena in so-called "Knoten" or knotty concretions often enclosing several sand grains and sometimes bounded by the crystal faces of the galena. The epigenetic character of the ore is beyond doubt.

American Occurrences. ${ }^{1}-\mathrm{On}$ the North American continent

${ }^{1}$ Dumble, E. T., First Ann. Rept. Geol. Surv. Texas, I889, p. 186.

Schmitz, E. J., "Copper Ores in the Permian of Texas," Trans. Am. Inst. Min. Eng., 26, 1896, pp. 1051-1052.

Emmons, S. F., "Copper in the Red Beds," in Bull. U. S. Geol. Survey No. 260, I905, pp. 22I-232.

Emmons, W. H., "The Cashin Mine," Bull. U. S. Geol. Survey No. 285, I906, pp. I25-I28.

Jennings, E. P., Trans. Am. Inst. Min. Eng., 34, p. 839. (Footnote continued on following page.) 
copper ores are of widespread occurrence in the Red Beds of the Southwest. They occur in Texas, Oklahoma, New Mexico, Arizona, Colorado, Utah and Idaho, always conspicuous by the colors of malachite and azurite, but rarely proving of economic importance. More success than elsewhere has attended their exploitation in New Mexico.

The ore occurs in arkose sandstone, conglomerate, and clayshale usually associated with plant remains and fossil wood. These strata were accumulated in shallow seas or as land deposits by a process of rapid degradation of adjacent land areas of the Rocky Mountain region. They have been referred to the Upper Carboniferous, Permian, Trias and Jura ; in part the identification of horizons difficult on account of lack of fossils, but it seems certain that they are present both in the Upper Carboniferous and the Jurassic.

In Texas they appear over large areas in Permian sandstones and shales at several horizons, in strata rich in plant remains; covellite, chalcocite, chalcopyrite, and pyrite are the minerals mentioned. They are said to extend from $33^{\circ}$ to $34^{\circ}$ in latitude and from $98^{\circ}$ to $100^{\circ}$ in longitude.

In Oklahoma occurrences are noted by Tarr in red shales and sandstones of probable Permian age; in Stillwater and Payne counties. Fossil wood is often converted to chalcocite, sometimes with a shell of chalcopyrite; here unusually high silver values of $3 \mathrm{I}$ ounces per ton are reported and traces of gold.

In Colorado these ores have been observed at several places, notably at Red Gluch, Fremont County, from where Lindgren describes nodules of chalcocite with barite in black carbonaceous shale; sections show that the copper sulphide actually replaces the

Turner, H. W., Trans. Am. Inst. Min. Eng., 33, p. 678.

Lindgren, W., Graton, L. C., and Gordon, C. H., "The Ore Deposits of New Mexico," 'Prof. Paper U. S. Geol. Survey' No. 68.

Gale, H. S., "Geology of Copper Deposits near Montpelier, Idaho, Bull. U. S. Geol. Survey No. 430, 1909, pp. I I2-12I.

Lindgren, W., “Notes on Copper Deposits," Bull. U. S. Geol. Survey No. 340, 1907, pp. 170-174.

Tarr, W. A., "Copper in the Red Beds of Oklahoma," Econ. Geol., 5, I9Io, pp. $22 \mathrm{I}-226$. 
shale, the lamination of which continues through the ore. Here also chalcocite replaces the coal of vegetable remains. The horizon is probably the uppermost Carboniferous. In northeastern Arizona, according to Gregory, ${ }^{1}$ small quantities of oxidized copper ores are frequently seen in the La Plata sandstone. North of the Colorado they appear in the Carboniferous of the Kaibab Plateau, probably leached from once covering Red Beds. South of the Colorado S. F. Emmons has described a deposit of oxidized ores and chalcocite in the Aubrey limestone near Grandview, which he considers having been leached from once overlying Red Beds and carried down into the limestone by descending waters.

In southwestern Colorado copper is widely distributed in the La Plata sandstone (Jurassic) often with vanadium ores. W. H. Emmons has described the Cashin Mine in this formation near Placerville. The ores are here argentiferous chalcocite, covellite, and bornite, with some calcite. No igneous rocks are present and Emmons believes the ores to be leached from the Red Beds. There is an active circulation of water in the formation and springs with salt, sulphates, and hydrogen sulphide abound. A production of about 300,000 ounces of silver and 700,000 pounds of copper is recorded from this mine.

The greatest development of the copper-bearing sandstones is in New Mexico; considerable production from picked ore has been achieved at the Nacimiento deposits in the northern part of the State where the Red Beds, considerably disturbed, rest on preCambrian granitic rocks which contain much older copper deposits. The beds have been referred to the Triassic on the evidence of fossil plants. According to F. C. Schrader (in pp. 68, U. S. G. S., cited above) most of the copper ores occur in the basal beds and are confined within a thickness of 25 feet in a reddish white sandstone rich in fossil wood, which is largely chalcocitized. A tree trunk 60 feet long with a basal diameter of $2 \mathrm{t} / 2$ feet is mentioned, which is almost wholly converted to copper glance. Besides malachite, azurite, and chrysocolla, there

${ }^{1}$ Gregory, H. E., oral communication. 
is some barite, and, at one place, cerussite. The low grade ores have not been utilized.

According to the same geologist, in the Zuni Mountains in northeastern New Mexico the copper-bearing beds again lie at the base of the Red Beds, resting on pre-Cambrian gneisses which contain copper veins. The sandstones, shales, and marls for 30 to 60 feet just above the base of the beds contain oxidized ores and galena replacing wood.

L. C. Graton describes in detail the ores from Tecolote district, San Miguel County, which are partly in the Red Beds of the Upper Carboniferous (Abo formation), partly in a higher horizon, perhaps the Dakota sandstone. The calcareous cement of the arkose is replaced by chalcocite, bornite, chalcopyrite and pyrite, the replacement extending into the feldspar grains.

In the Oscura Range red sandstones, probably also of the Carboniferous Red Beds, contain chalcocite, bornite and chalcopyrite, in part as replacement of fossil wood. Turner mentions the occurrence of plant remains from this place, said to have been identified as the Triassic Podozamites crassifolia, the same cycad which is characteristic of the deposits at Abiquiu first studied by Newberry.

Graton believes, contrary to Turner, that the copper ores have been introduced into the strata from a number of dislocations cutting the sandstone.

Finally, H. S. Gale describes copper ores from southern Idaho which occur in the Ankareh Maroon shales and sandstones of the Trias or Carboniferous (equivalent to the Permo-Carboniferous of the Fortieth Parallel Survey). A thick limestone (including the Meekoceras beds) underlying these shales is believed to be Triassic by some geologists.

There are then at least two main cupriferous horizons in the Southwest: (I) The Upper Carboniferous Red Beds, equivalent to the Permo-Carboniferous, or the Abo formation; (2) the undoubtedly Jurassic, La Plata sandstone.

The silver deposits in the supposedly Triassic sandstones of 
Silver Reef ${ }^{1}$ in Southern Utah (Harrisburg district), which created quite a boom about I88o, are now only worked on a small scale. The ores were silver chloride above the water level and native silver and argentite in depth; copper was also present, and selenium is reported. Plant remains were abundant. On the whole a secondary concentration from a primary argentiferous chalcocite is the most probable explanation. It has already been emphasized that the chalcocite universally carries silver, though in the ordinary occurrences the tenor is rarely above Io ounces per ton.

South America.-The well known and long worked copper deposits of Coro-Coro ${ }^{2}$ in Bolivia, a series of standstones, believed to be of Permian age, here contain several beds impregnated with native copper with some native silver, domeykite and chalcocite, also much gypsum. The copper-bearing horizons are much lighter in color than the prevailing deep red sandstones.

According to Steinmann the strata are of Cretaceous age and the copper was introduced by hot waters derived from an intrusion of diorite. Nevertheless the descriptions suggest strongly that the deposits belong in a different class.

Africa.-Sufficient information is not at hand to decide whether the recently opened Katanga ${ }^{3}$ ores of southeastern Belgian Kongo, near Rhodesia, belong in this division. Large masses of high grade oxidized copper ores are contained in sand-

'Roelker, "The Silver Sandstone District of Utah," Trans. Am. Inst. Min. Eng., 9, 188I, pp. 2I-33.

Rothwell, "The Silver Sandstone Formation of Silver Reef," Eng. and Min. Jour., 29, 1880, pp. 25, 48, 79.

Newberry, "Report on the Property of the Stormont Silver Mining Company," 30, 1880, p. 269; 21, I88I, pp. 4-5.

Kemp, "Ore Deposits of United States," 1900, p. 334.

"Older literature: See Stelzner-Bergeat (I.), p. 4I9.

Steinmann, G., Rosenbusch Festschrift, I906, pp. 335-368.

"Farrell, J. R., "The Copper and Tin Deposits of Katanga," Eng. and Min. Jour., 85, April II, I908, p. 564 .

Buttgenbach, H., "Les gisements de cuivre de Katanga," A. S. Geol. de Belge, 3I, 1904, p. 515.

Ball, S. H., and Shaler, M. K., "Mining Conditions in the Belgian Congo," Trans. Am. Inst. Min. Eng., 1910. 
stones, shale, and limestone, probably of Paleozoic age. The ores are of high grade ( 8 to I 2 per cent. copper) and are stated to contain a little gold and silver; some manganese, cobalt, and nickel are present. Barite and quartz appear as gangue minerals. A deposit at Ruwe, in the same general region described by Ball, contains in a sandstone, a most curious association of ores yielding gold, platinum, silver, palladium, vanadium, nickel, lead and copper, the last two metals as vanadates. In some ways this deposit suggests the type now under description.

GENESIS.

The epigenetic character of the copper deposits in sandstone is proven beyond reasonable doubt. The replacement of coal, carbonaceous shale, and calcareous sandstone cement by chalcocite is proven. The gangue minerals are few and quartz is conspicuously absent. Barite in small amounts is rather common. Irregularity in dissemination is typical, though the ores often follow certain horizons rather persistently. The entire independence of the occurrence of igneous rocks is marked. The difference between these deposits and the ordinary type of fissure vein is striking, and they can not have been formed in the same manner. It is necessary to explain why chalcocite is characteristic of the first and chalcopyrite of the second type.

The occurrences are mainly on the flanks of older continental areas containing pre-Cambrian copper deposits; the sandstones were rapidly deposited as arkoses indicating a long epoch of rock decay, the products of which were rapidly swept away during a following arid epoch. Considering the evidence as a whole the sedimentary deposits must contain finely divided copper ores in part from solutions derived from the land area, in part as cupriferous detritus. When atmospheric waters charged with salt and gypsum searched these beds they must have taken this copper into solution and concentrated it in certain horizons when reducing substances like coaly vegetable matter were available. In most cases the solution probably contained the copper as sulphate, though where much salt was present it might well 
have been transformed into chloride; or where $\mathrm{H}_{2} \mathrm{~S}$ was available it might have been carried in solution as sulphide.

It does not follow that all deposits of copper ores in sandstone and shale belong to this class here described, for an impregnation by ascending thermal solutions of foreign origin is a possible contingency in some instances.

In the precipitation the most important chemical reactions were those between the carbonaceous matter of plant remains and the calcareous cement or the kaolin in the sandstone on one hand and the cupriferous solutions on the other hand.

\section{VANADIUM ORES IN SANDSTONES.}

The preceding pages show that the copper deposits often carry some vanadium as vanadinite or volborthite. Lately vanadium with some uranium has been shown to be common in certain sedimentary horizons in Colorado and Utah. The deposits in Western Colorado are now worked and experimental plants for their reduction are being erected at Newmire, near Placerville. $^{1}$ Some of the sandstone near Placerville contained $3.5^{\circ}$ per cent. $\mathrm{V}_{2} \mathrm{O}_{3}$ and 0.05 per cent. $\mathrm{UO}_{3}$. Shipments are said to have contained as much as I I. 5 per cent. $\mathrm{U}_{3} \mathrm{O}_{8}$ and 6.40 per cent. $\mathrm{V}_{2} \mathrm{O}_{5}$, but on the whole the grade is probably low.

In all these states the vanadium ores appear to occur in the Jurassic limestone of the La Plata formation. The best known localities are near Placerville in the La Sal, Paradox, and Sindbad valleys. The ores follow certain horizons or appear in fissures and brecciated places; they are often associated with plant

${ }^{1}$ Hess, F. L., “Min. Res. U. S.,” I907, p. 721.

Merrill, G. P., "Non-metallic Minerals," I904, pp. 299-320.

Hillebrand, W. F., and Ransome, F. L., "Carnotite, etc., in Western Colorado," Am. Jour. Sci., 4th Ser., Io, 1900, pp. I20-144. In Bull. U. S. Geol. Survey No. 262, 1905, pp. 9-13. State Bureau of Mines, Colorado, Rept. 1905-1906.

Boutwell, J. M., in Bull. U. S. Geol. Survey No. 26o, 1905, p. 205.

Gale, H. S., "Carnotite in Western Colorado," in Bull. U. S. Geol. Survey No. 340 , 1908.

Gale, H. S., "Carnotite in Rio Blanco County, Colorado," in Bull. U. S. Geol. Survey No. 315, 1906, pp. I10-117. 
remains. The occurrences are all within the Great Plateau province of horizontal or gently inclined strata.

The most prominent mineral is the bright yellow powdery carnotite, to which Fuchs and Cumenge give the formula ${ }_{2} \mathrm{U}_{2} \mathrm{O}_{3}, \mathrm{~V}_{2} \mathrm{O}_{5}, \mathrm{~K}_{2} \mathrm{O},{ }_{3} \mathrm{H}_{2} \mathrm{O}$, but Hillebrand doubts whether the formula is as simple as this. One of his analyses of carnotite from Roe Creek gave:
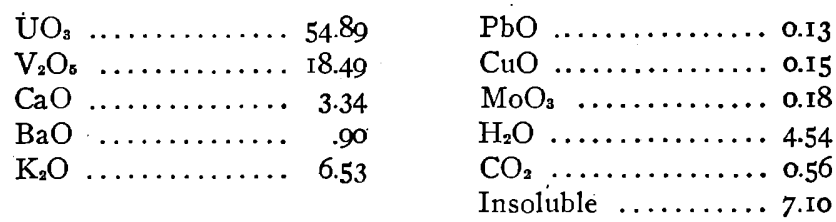

Copper as green stains of malachite, brochantite and azurite is commonly present in the deposits and frequently also lead. Hildebrand also found some molybdenum, arsenic, a selenite of copper, and some manganese. Roscoelite, a vanadium mica develops in the calcitic or kaolinic cement of some of the sandstones in southwestern Colorado. This mineral carries only a small amount of oxide of vanadium, but is present in the richest olive-colored beds to the extent of 20 per cent. Lately a black mineral of doubtful composition, probably a vanadium oxide, has been found in this region and it is indeed possible that carnotite is a secondary product of an unknown primary vanadium mineral. The roscoelite has probably not been altered since its first deposition. In the Utah beds Boutwell found vanadates of copper such as volborthite and calcio-volborthite.

Not similar to these deposits, yet perhaps of a similar origin, are the recently discovered important vanadium deposits at Minasragra, ${ }^{1 \cdot}$ near Quisque, Province of Pasco, Peru, described by D. F. Hewett.

The vanadium sulphide, patronite, occurs here on a large scale as greenish black masses associated with a hydrocarbon and a

${ }^{1}$ Hewett, D. F., "Vanadium Deposits of Peru," Trans. Am. Inst. Min. Eng., 40, 1909, pp. 274-299.

Hillebrand, W. F., “The Vanadium Sulphide Patronite,” Jour. Am. Chem. Soc., 29, 1907.

Hillebrand, W. F., Am. Jour. Sci., 4th Ser., 24, I907, p. I4I. 
peculiar nickel-bearing pyrite. An analysis of the patronite gave 58.79 per cent. sulphur, 19.53 per cent. vanadium, o.I8 per cent. molybdenum, I.87 per cent. nickel, and 3.47 per cent. carbon. The mineral forms a vein with much bitumen and clay in gently dipping cretaceous strata. Igneous rocks are present in abundance and may be responsible for the peculiar development of a new type of ore.

Genesis.-Traces of vanadium are found, according to Hillebrand, in most igneous rocks. Smaller quantities occur as oxidation products in many ore deposits, mostly as vanadinite or descloizite. More abundantly vanadium occurs in sedimentary rocks such as clays and shales; it is also concentrated in coal; the ashes of many varieties are rich in vanadium. ${ }^{1}$ This peculiar relationship has not been fully explained; at any rate the processes of weathering and vegetation appear to be favorable to the concentration of vanadium; and, to some extent, uranium shares in this behavior. The association of vanadium and copper in the ore-bearing sandstones has already been emphasized, as well as their frequent occurrence with coal or vegetable remains.

Viewing the evidence as a whole the vanadium deposits described above are probably products of concentration, by surface waters of small quantities of the metal distributed through littoral beds or land deposits of sandstone and clays.

THE COPPER-BEARING SHALES OF MANSFELD. ${ }^{2}$

The celebrated cupriferous shale (Kupfer schiefer) of Mansfeld in central Germany, though not identical with the deposits described in this chapter, presents most interesting analogies to them.

A flourishing mining industry is still based on the "Kupfer schiefer," the annual ore production being approximately 700,000 metric tons of ore containing between 2 and 3 per cent. of copper.

' ${ }^{1}$ See Clarke, F. W., "The Data of Geochemistry," I9o7, p. 6ir. A coal from the copper deposits in sandstone of Red Gulch, Colorado, contained, according to Hillebrand, o.I8 per cent. vanadium.

"Best description with literature in Stelzner-Bergeat: "Die Erzlagerstätten," I, pp. 39I-417. 
The first stratum deposited in the subsiding basin of the Upper Permian in central Germany was a marine conglomerate of slight thickness. "Above it extends like a black shroud the thin bed of cupriferous shale, one of the most remarkable products of the geological ages. Characterized by its fauna as a shallow-sea deposit, full of plant remains carried in from adjacent coasts, the formation bears the stamp of an organic mud deposit admixed with an organic precipitation."1

Above the cupriferous shale, which is less than I meter thick, extends a marine limestone (Zechstein), 8 to Io meters thick, and above that lie the great gypsum and salt masses of the uppermost Permian. Folding and faulting have since affected the beds, and the mining now follows the inclined strata to a depth of 500 meters.

The cupriferous bed averages 50 centimeters in thickness, but only the lower part of $20-30$ centimeters is mined.

The ores are sulphides, in minute distribution through the shale giving it a bronzy appearance. Chalcopyrite predominates, but there is also bornite, pyrite, chalcocite, rarely galena and tetrahedrite. Small quantities of nickel, cobalt, selenium, vanadium, and molybdenum have been recognized; there is also o.oro-0.0I 5 per cent. of silver. Zinc is present and in the upper part of the bed, not mined, there is more zinc than copper. An average analysis is as follows: ${ }^{2}$

Average Analysis of Cupriferous Shale.

(Dr. Haase, Analyst.)

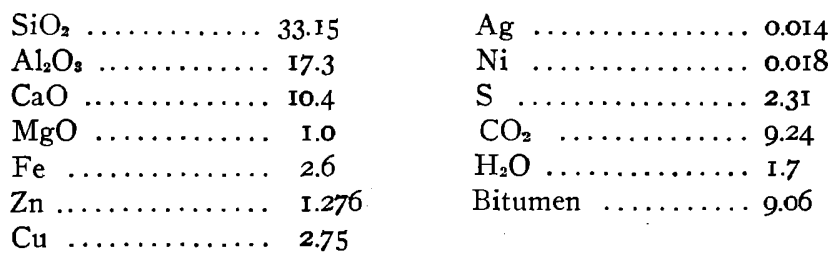

There is about 3 per cent. $\mathrm{K}_{2} \mathrm{O}$ and $\mathrm{I}$ per cent. $\mathrm{Na}_{2} \mathrm{O}$; lead amounts in place to $\mathrm{I} .5 \mathrm{O}$ per cent., manganese to about 0.25 per cent.

\footnotetext{
${ }^{1}$ Beyschlag, F., In "Deutschlands Kalibergbau," 1907, p. 4.

${ }^{2}$ Stelzner-Bergeat, I, p. 396.
} 
There is practically no gangue, except veinlets of gypsum and barite. The bed is cut by faults, which in places contain barite, anhydrite, calcite, niccolite, pyrite and chalcopyrite, and near these (the so-called "Rücken") the metal content is subject to enrichment, impoverishment or removal upwards in adjacent beds. Bergeat asserts that these changes take place on secondary fissures and cracks.

There has been much controversy about the Mansfeld deposits. The majority of geologists regard them as sedimentary and syngenetic: v. Groddeck, Stelzner, Freiesleben, and von Cotta held this view, and it is shared by Bergeat. Posepny and Beck believe them epigenetic and probably introduced into the shale from the "Rücken."

The "Kupfer schiefer" is certainly not an ordinary marine deposit precipitated from the sea water. ${ }^{1}$ It was laid down in a shallow sea full of decaying vegetable and animal remains into which cupriferous waters from the surrounding littoral was discharged, most likely sulphate solutions derived from the eruptives of the early Permian epochs. No one can read the description of the great uniformity of distribution without being impressed with the very strong arguments for a syngenetic origin.

At the same time it is proper to call attention to the characteristic presence of nickel, cobalt, vanadium and selenium which recalls the epigenetic deposits in sandstone so abundant around the shores of the Permian sea, in Bohemia and Russia, for instance. The Mansfeld basin was simply then the final collecting place of the solutions derived from adjacent desert shores.

${ }^{1}$ It is well known that sea water does contain a little copper, as shown among others by Dieulafait (Am. Chim. phys., 5th Ser. 18, 1879, p. 359; also $C . R$., 90, 1573; pp. 96, 70, IOI, 1297), but it seems utterly insufficient to account for the Mansfeld deposits. 